3,347 million francs was spent on research and 2,901 million franes on development.

\section{Scientists in Mexico}

Part $1(A-G)$ of the volume on Mexico in the series Scientific Institutions and Scientists in Latin America, issued by the Centre for Scientific Co-operation in Latin America of the United Nations Educational, Scientific and Cultural Organization and the Organization of American States, contains the information regarding scientists in Mexico which was contained in the earlier three volumes issued in 1951, and in 1955 brought up to date and with many new ieferences (Pp. 372. Monte. video, 1965).

\section{Royal Geographical Society: Awards}

The Royal Geographical Society has announced the following medals and awards for 1966: Patron's Medal, Prof. E. J. H. Corner, leader, Royal Socioty Exp€ditions to North Borneo and the Solomon Islands; Founder's Medal, G. Hattersley-Smith, for glaciological investigations in the Canadian Arctic; Victoria Medal, G. R. Crone, librarian and map curator, Royal Geographical Society; Murchison Grant, Prof. S. G. Davis, University of Hong Kong; Back Grant, Dr. S. Evans, Scott Polar Research Institute, Cambridge; Cuthbert Peek Grant, Lieut. Commander M. K. Burley, leader, Combined Services Expedition to South Georgia; Gill Memorial, P. Haggett, University of Cambridge; Mrs. Patrick Ness Award, E. C. Evans and J. P. M. Long, Welfare Branch, Northern Territory Administration, Government of Australia.

\section{University News:}

Belfast

DR. K. J. Ivin, at present reader in physical chemistry in the University of Leeds, has been appointed to the chair of physical chemistry.

\section{Bradford Institute of Technology}

Dr. A. BotromLey, at present Ford Foundation adviser to the Institute of Public Administration and Development of the Lebanese Government, has been appointed professor of economics. Dr. W. R. A. D Moore, reader in high polymer chemistry at the Institute, has been appointed professor of polymer science.

London

Prof, A. C. Offord, at present professor of mathematies at Birkbeck College, has been appointed to the chair of mathematies at the London School of Economics and Political Science. Dr. G. R. Davis, resident mining consultant in Northern Rhodesia to the British South Africa Co., has been appointed to the chair of mining geology tenable at the Imperial College of Science and Technology. Dr. P. J. Grant, at present reader in engineering science at the Imperial College of Science and Technology, has been appointed to the chair of nuclear power tenable at that College.

\section{Announcements}

Dr. N. P. Alleen and Dr. O. Simpson have been appointed deputy directors at the National Physical Laboratory as from April 1. Dr. Allen, who joined the National Physical Laboratory as superintendent of the Metallurgy Division in 1944, will become deputy director (A), and Dr. Simpson, who joined the Laboratory in 1963 as superintendent of the Basic Physics Division, will become deputy director (B).

Tre sixteenth annual meeting of the Société de Chimie Physique will be held in Paris during May 31-June 3. Further information can be obtained from Prof. G. Emschwiller, Société de Chimie Physique, 10 rue Vau. quelin, Paris 5.
A COURSE on "Life in the Past", arranged by the Joint Biology Committee, will be held in the University of London on May 21. Further information can be obtained from the Treasurer, Joint Biology Committee, $11 a$ Lonsdale Gardens, Tunbridge Wells, Kent.

AN international symposium on "Electron Microscopy and Cytochemistry" will be held in Leiden during May 30 June 4. Further information can be obtained from the Secretariat of the Symposium, Laboratory for Electron Microscopy, 62 Wassenaarseweg, Leiden.

A REVIEw symposium on "Modern Applications of Thermoelectricity" will be held at the Welsh College of Advanced Technology during April 20-22. Further information can be obtained from the Organizer of Short Courses, Welsh College of Advanced Technology, Cathays Park, Cardiff.

A SYMPOSIUM on "Traffic Safety-a National Problem" will be held in Washington on April 28, during the second annual meeting of the National Academy of Engineering. Further information can be obtained from the Secretary, National Academy of Engineering, 2101 Constitution Avenue, Washington, D.C.

A Convention on "Thermodynamics and Fluid Mechanics", arranged by the Thermodynamies and Fluid Mechanics Group of the Institution of Mechanical Engineers, will be held in Liverpool during April 13-15. Further information can be obtained from the Institution of Mechanical Engineers, 1 Birdcage Walk, Westminster, London, S.W.1.

THE spring meeting of the Western States Section of the Combustion Institute will be held at the Denver Research Institute during April 25-26. The subjects under discussion will be: fire research; pyrolysis of solid fuels and oxidizers; high-pressure, condensed-phase reactions; metal combustion. Further information can be obtained from the Secretary, Western States Section, the Combustion Institute, 16902 Bollinger Drive, Pacific Palisades, California.

AN international symposium on "Generalized Networks", arranged by the Microwave Research Institute of the Polytechnic Institute of Brooklyn, in co-operation with the Institute of Electrical and Electronics Engineers, the Optical Society of America and the Society for Industrial and Applied Mathematics, will be held in New York City during April 12-14. Further information can be obtained from the Symposium Committee, Polytechnic Institute of Brooklyn, 333 Jay Street, Brooklyn, N.Y.

A symposrum on "Advances in Polymer Characterization", organized under the auspices of the Manchester and District Advisory Council for Further Education, will be held in the University of Manchester during April 20-21. The programme will include sessions on: solution properties and the determination of molecular weight distributions; characterization of tacticity; properties of amorphous polymers; crystallinity and crystallization. Further information can be obtained from the Registrar, Manchester College of Science and Technology, Manchester.

THE fifth general meeting of the International Mineralogical Association will be held at Cambridge during August 30-September 3. The programme will include symposia on crystal growth with special reference to minerals or bonding forces in mineral structures and on pyroxenes and/or amphiboles, and an evening session on problems of the quantitative measurement of reflectivity in ore minerals. Further information can be obtained from the Local Secretary, International Mineralogical Association Meeting, Department of Mineralogy and Petrology, Downing Place, Cambridge. 